\title{
Review of the Skill Development Initiatives and its Effect on the Indian Economy
}

\author{
S. Srivathsani ${ }^{1}$ and S. Vasantha ${ }^{2^{*}}$ \\ ${ }^{1}$ Research Scholar, ${ }^{2}$ Professor, School of Management Studies, \\ Vels Institute of Science, Technology \& Advanced Studies (VISTAS), Chennai, Tamil Nadu, India \\ *Corresponding Author \\ E-Mail: srivathsani@gmail.com, vasantha.sms@velsuniv.ac.in
}

\begin{abstract}
Skill can be related to the work performed by the people. If a unit of work is performed by an unskilled person, the actual output would not match the expected output. Thus, skills and competencies play an important role in a person's life. The projection of the skills and competencies helps him to achieve the employability status. The person has to sustain his employability by the process of continuous enhancement of his skills by way of various trainings and workshops. So, skills are essential for the development of a person and the country's economy. This paper deals with the study of the current skill gap scenario prevailing in India and various schemes and programmes propelled by the Government of India to bridge the gap. The paper also discusses the National Policy on Skill Development and Entrepreneurship 2015.

Keywords: Skill, Skill Development, Employability, NSDC, MSDE, Economy, NSDA
\end{abstract}

\section{INTRODUCTION}

Skill is related to the capability of a person to complete a task in accordance with the pre-determined results. Skill has been defined as an ability and capacity developed through thoughtful, cautious, systematic, and persistent effort to efficiently and successfully accomplish multi-faceted activities or job functions involving ideas (intellectual skills), resources like computer software or hardware (specialized and practical skills), and/or people (social interactive skills) in [1].

\section{A. Necessity of Skills}

Skills are necessary for a person to develop and progress in his/her career. He must have the capability to adapt himself to the fast and rapidly changing environment around him. A person is required to project his/her skills to the prospective employer to attain the employable status. According to the article published on macmillanenglish website, enhancement of life skills is proving to be beneficial to the individual, employer and society as a whole. The need for skills is also explained by careerwise.minnstate.edu website. They state that possession of skills makes a person very confident. The employers get a positive outlook about the candidate who possesses skills. Skills and knowledge are dynamic, motivating and influential forces of economic evolution and social progress for any country. Countries with advanced and sophisticated education levels and improved benchmarks related to skills and competencies can adapt more effectively and productively to the challenges and opportunities in national and international job markets.

\section{OBJECTIVES OF THE STUDY}

1. To explore the need for skill gap analysis.

2. To review the literature on skill development initiatives taken by the Government of India.

3. To do an in-depth study of NSDC, NSDA,SSC and DGT bodies.

\section{RESEARCH METHODOLOGY}

The study is based on secondary sources of data or information. Different online news reports, government websites like msde.gov.in, vikaspedia.in and Government Publications related to policy have been referred to make an in-depth analysis.

\section{LITERATURE REVIEW}

\section{A. Skill Gap Analysis}

The skill gap can be defined as the discrepancy between the competencies that employers desire to be present in the prospective candidate and those that are available in the workforces, who are on the lookout for a job [2].

Skills gaps purely refer to the substantial variation between the skills that the organisation requires from its workforce and the skills that the workforce extends. A detailed analysis of the skills gaps has been performed in the public service according to the subdivisions existing in the department. It lays emphasis on recognizing the mandatory skills that are required for the employees working in a department at a particular level and evaluate them against the skills possessed by the employees. In addition to this, it is also intended at investigating the current competency level of the staff working in the public service sector have the required aptitudes and competencies that they need to execute their job functions correctly and if not, the skills for which they need to go undergo training. The study also proposes to set standards while recruiting new persons [3]. 
A report titled Global Growth Index by Epicor Software is mentioned in [4]. The report findings are that around 23\% of businesses felt that they are able to find the right person with adequate skills easily. They also managed to find people with the appropriate industry awareness and understanding but they fear they may face deadlock situation sooner. The research was carried out among 2500 business administrators and employees in businesses in 14 countries, including India. It was found out that $32 \%$ of businesses believe that there is a dearth of right skills or experience among young people to work in the industry.

The MSDE policy [5] states that around 5\% of the total human resources in India only has undergone official, recognized skill training. For most of the developed countries, it ranges between $68 \%$ to $96 \%$. Considering demand side, a skill gap analysis had been organized by NSDC over 2010-2014, which indicates that there is an additional requirement of 109.73 million skilled personnel by 2022 in twenty-four key sectors.

There are many ways by which the skill gap can be identified [6]. They are:

1. Observe the performance of an employee for a period of time. The companies usually have a performance appraisal system where the employees are asked to fill the details of the work done in that period. The team leader provides inputs on the areas where the employee has performed well, areas of improvement which needs to be addressed within the next appraisal.

2. The skill gap can also be identified by using KPIs.KPIs mean Key Performance Indicators.KPIs help the employees in their progression, compensation etc.

The skills gap investigation can really bring progress and advancement in an organization if the managers provide a judicious outline of the standards which the workforce has to meet. If employees do not have these skills, an organization can use the skills gap analysis to assist them with the necessary specialized training workshops rather than providing them with a generalized training. This helps them save training costs [7].

The skill gap can be addressed through skill development training. Skill Development helps build a nation with empowered individuals. The Ministry of Skill development and Entrepreneurship website [8] states that around 65\% of the youth belongs to the employed category. To reap the maximum benefits out of this population and create a knowledgeable and skilled economy, our Honourable Prime Minister has taken up the mission of "Skill India". The vision of accomplishing "Skill India" is launched with an idea to empower the youth of India with the skills necessary for them to survive in this ever-demanding, constantly evolving, fast progressing technology world.

The "Skill Mission" was launched on 15 July 2015.It has garnered a lot of support and reviews under the leadership of Shri Dharmendra Pradhan, Minister for Skill Development and Entrepreneurship and Shri Anant Kumar
Hegde, Minister of State, MSDE. More than one crore youth link themselves with the Skill India mission yearly. Skill India is not constrained only to addressing the demands of the Indian market but it is vigorously getting involved with countries across the world to project India in limelight in a global arena and create opportunities for the country's youth in the international market. The skilled workforce of India will not only be able to showcase their talents and excel in their motherland but they would also be able to contribute globally.

\section{SKILL DEVELOPMENT INITIATIVES IN INDIA}

The skill growth in India is taken care of by the Ministry of Skill Development and Entrepreneurship (MSDE). The Ministry is accountable for bringing together all skill improvement activities across the country and synchronize it, elimination of increasing divide between requirement and provision of personnel with adequate skills and industry experience, developing quality professional and methodological training institutions, skill enhancement and enrichment, encouraging new skills and be a catalyst for the workforce to come up with revolutionary and path-breaking ideas.MSDE thus encourages the youth by fostering creativity, innovation in them, which leads to the path of entrepreneurship.

The Ministry aims to march forward efficiently and swiftly to accomplish its vision of a 'Skilled India'. It is supported in this programme by efficient and well-designed organizations named National Skill Development Agency (NSDA), National Skill Development Corporation (NSDC), National Skill Development Fund (NSDF) and 33 Sector Skill Councils (SSCs) as well as 187 training partners registered with NSDC.

MSDE is a vital component of the government policy based on "Sabka Saath, Sabka Vikaas" and it is committed to an all-inclusive progression of the population, which spans from rural to urban areas. In view of this, MSDE had come with a policy which addresses the entire population. The policy is named as "National Policy on Skill Development and Entrepreneurship 2015" [5]. National Skill Development and Entrepreneurship Policy 2015 attempts to focus on many issues. It endeavours to create a bond between the world of edification and the world of employment. The result of this bonding is to empower these two different worlds to build a Skilled India. The Mission of "National Policy on Skill Development and Entrepreneurship 2015" policy is to

1. Generate the need for skill development across the country.

2. Associating skills with the appropriate competencies.

3. Relate and establish a link between the skilled human resources and demands of the industry.

4. Make sure the standards set by the policy match to the international levels.

5. Design an environment which encourages creativity and innovative ideas, thus leading to the development 
of a productive, revolutionary and leading-edge economy.

The various organizations which work hand-in-hand with MSDE are:

\section{A. NSDC}

The National Skill Development Corporation India (NSDC) was formed to function as a Public Private Partnership Company. The most important objective is stimulating the skills environment in India. NSDC is centred on the following towers of strength:

1. Taking initiatives to create professional training institutions which exhibit excellence and class. The institutions must be empowered with the infrastructure to cater to the huge population.

2. By providing long-term capital to the sector skill councils

3. Empowering the foundation and ensuring the prolonged continuity of support systems required for skill development. This comprises of the Industry led Sector Skill Councils.

The key goals of the NSDC are to:

1. Elevate the level of skills to international standards through substantial on the job training pertaining to that industry and develop essential outlines for standards, curriculum and also design procedures for quality assurance

2. Work in coordination with the private sector and support their initiatives for skill development through suitable Public-Private Partnership (PPP) models. Make efforts for provision of significant functional and commercial involvement from the private sector.

3. Create financing opportunities in sectors which are yet to be explored or have not been marketed effectively.

4. Give importance to initiatives that address multiple objectives than the ones which address a single objective.

NSDC works in collaboration with Private sector companies, central and state ministries, NGOs and higher educational institutions.

Some of the achievements of NSDC are as follows:

1. Around 5.2 million students have been trained.

2. Established 235 private sector partnerships for training and competency development.

3. 38 Sector Skill Councils (SSC) sanctioned in services, manufacturing, agriculture \& allied services, and informal sectors.

4. 1386 Qualification Packs with 6,744 unique National Occupational Standards (NOS). The standards have been authenticated by over 1000 companies.

5. Professional training introduced in 10 States, covering 2400+ schools assisting over 2.5 lakh students. Curriculum based on the National Occupational Standards (NOS) and SSC certification has been designed. NSDC is working with 21 universities,
Community Colleges under UGC/AICTE for aligning the standards of education according to the National Skills Qualifications Framework (NSQF).

\section{B. National Skill Development Agency (NSDA)}

The National Skill Development Agency (NSDA), a selfgoverning body, (enlisted as a Society under the Society's Registration Act 1860) was designed with the purpose to synchronize and complement the skill promotional endeavours in the country.

Functions of NSDA:

1. Anchor the National Skills Qualifications Framework (NSQF) \& simplify the procedure of setting up professional certifying bodies. This is done to set standards to be on par with the international paradigms.

2. Ensure that steps are taken to match the targets related to aptitudes and competencies as visualized in the 12th Five Year Plan and beyond.

3. Organize and work along with various Central Ministries/Departments, State Governments, the NSDC and the private sector to promote skill enhancement activities.

4. Assess the prevailing skill development schemes to judge their effectiveness and provide suggestions for corrective action so that they are able to achieve the intended objectives.

5. Build and sustain a national repository related to skill development including development of a dynamic Labour Market Information System (LMIS).

\section{Sector Skill Councils}

The National Skill Development Policy of 2009 had directed the NSDC to come up with SSCs with an objective to connect the key participants i.e. employers, employees and the academic world. They are currently sponsored by NSDC and are anticipated to grow into an economically self-sponsored organisation in few years. These SSCs are in-charge of formulating the National Occupational Standards for different levels of jobs in several sectors, chart out certification and accreditation norms, take efforts to build data warehouse pertaining to the current requirements of skill development in the industry, examine the quality of the supply of competent and proficient workers, explore the demand and supply gap in each sector and forecast the trends to design the skill development programmes accordingly.

\section{Directorate General of Training (DGT)}

The Directorate General of Training comprises of the Directorate of Training and Directorate of Apprentice Training. This incorporates a chain of Industrial Training Institutes (ITIs) in States, Advanced Training Institutes (ATIs), Regional Vocational Training Institutes (RVTIs) and other central institutes. Numerous training programmes addressing the needs of the students, trainers and industry requirements are being conducted by these institutes. ITIs 
have a significant contribution to the Indian economy by delivering skilled manpower in several sectors with differing levels of proficiency and capabilities. ITIs are affiliated by National Council for Vocational Training (NCVT).

\section{SCHEMES RELATED TO SKILL DEVELOPMENT}

1. Deen Dayal Upadhyaya Grameen Kaushalya Yojana: This scheme aims at providing skill training to the poor people in the rural areas. It works for supporting the people in rural areas in terms of financing, providing assistance for job placements, post-placement support activities etc.

2. The scheme for financial Assistance for Skill Training of Persons with Disabilities is eligible for people with not less than $40 \%$ disability and having a certificate associated with their health .This certificate must be provided by a skilled and experienced medical practitioner.

3. Apprenticeship Training is contemplated to be one of the most cost-effective ways to cultivate skilled manpower for the country. It provides a platform for on the job, real-world, useful form of formal training. National Apprenticeship Promotion Scheme has been developed to promote internship training in the country.

\section{DISCUSSION}

As seen from above, there are many avenues through which skill development of an individual can take place. The responsibility also lies with the individual to take initiatives from his side. The Government has to take measures to provide the ITIs, vocational training institutions with adequate infrastructure, assure that the trainers are skilled and competent enough to train the students and also ensure that the skill development programmes are funded adequately by the contributions from public and private organizations.

\section{CONCLUSION}

If the "Skill India" mission is implemented efficiently with the help of MSDE, NSDC, NSDA and SSCs, days are not far away when there would exist no gap between supply and demand of skilled workers. The People of India must understand that Skill Development and formal education go hand in hand and it has a big hand in the progression of the economy of the country.

\section{REFERENCES}

[1] What is skill? Meaning and Definition. Retrieved from http://www.businessdictionary.com/definition/skill.html

[2] The Skills Gap. Retrieved from https://www.skillsyouneed.com/ general/skills-gap.html

[3] Mkhonza, L. and Letsoalo, A. (2017). Understanding the Skills Gaps in the Public Service Sector. Public Service Sector Education and Training Authority, Pretoria.

[4] Skill Gap A Major Problem In Attracting The Right Talent. (2018). Retrieved from http://www.businessworld.in/article/Skill-Gap-AMajor-Problem-In-Attracting-The-Right-Talent-/07-06-2018-151460/

[5] National Policy on skill development and Entrepreneurship. (2015) Retrieved from https://www.msde.gov.in/assets/images/Skill\%20 India/National\%20Policy\%20on\%20Skill\%20Development $\% 20$ and $\%$ 20Entreprenurship\%20Final.pdf.

[6] 5 Approaches on How to Identify Skill Gaps at Work Nikos Andriotis, (2017). Retrieved from https://www.efrontlearning.com/ blog/2017/10/identify-skill-gaps-workplace.html

[7] Mallikarjun Koripadu \& K. Venkata Subbiah. (2014). Skill Gap Analysis for Improved Skills and Quality Deliverables.

[8] Retrieved from https://www.msde.gov.in.

[9] Retrieved from http://vikaspedia.in/social-welfare/skill-development. 